\title{
PM1O EXPOSURE AND RESPIRATORY TRACT DISORDERS AROUND THE INDUSTRY: A SYSTEMATIC REVIEW
}

\author{
Lilian Susanti Nova
}

Research and Public Health Development Center, National Institute of Health Reseach and Development, Indonesia Ministry of Health

\begin{abstract}
Background: Air pollution from industrial activities and motor vehicle emission disrupt respiratory tract in the community. People who live around the industry are at risk of experiencing respiratory problems. PM10 measurement is needed to determine the quality of ambient air in accordance with the established quality standard. This study aimed to systematically review PM10 exposure and other factors associated with respiratory tract disorders around the polluting industry.

Subjects and Method: This was a systematic review conducted by searching articles from Google Scholar database. The keywords were "acute respiratory infection", "ARI", "PM10", and "community". The study population was people who live around the industry exposed to PM10 and those not exposed. The inclusion criteria were articles published in the range of 5 years around 2014 to 2019, located in Indonesia, cross-sectional study, and published in Indonesian or English language. The exclusion criteria were articles without complete file unit and not located in Indonesia.

Results: Five articles were reviewed out of 176 articles obtained. The articles reported that factors affecting the occurrence of respiratory tract disorders were age, sex, occupancy density, smoking in the house, ventilation, and PM10 concentration in the exposed community.

Conclusion: Several studies have linked PM10 exposure with respiratory tract disorders in the communities living around the polluting industries. There is a need for handling the poor air quality.
\end{abstract}

Keywords: PM10, industry, respiratory tract disorders, community

\section{Correspondence:}

Lilian Susanti Nova. Research and Public Health Development Center, National Institute of Health Reseach and Development, Indonesia Ministry of Health. Jl. Percetakan Negara No. 29, $5^{\text {th }}$ Floor, Jakarta 1560, Indonesia. Email: lilian.sn82@gmail.com. Mobile: 081380870581.

The $6^{\text {th }}$ International Conference on Public Health

Best Western Premier Hotel, Solo, Indonesia, October 23-24, $2019 \mid 45$ https://doi.org/10.26911/the6thicph.01.22 